\title{
Effects of Cattle Grazing on Mountain Mea- dows in Idaho
}

THOMAS A. LEEGE, DARYL J. HERMAN, AND BENJAMIN ZAMORA

\section{Abstract}

Vegetation changes which occurred during 12 years of protection from grazing were documented in mountain meadows of north-central Idaho. Plant composition changes were evident on all five sites studied, whereas herbage production was significantly less on the grazed than ungrazed areas at two of the sites. Seasonlong grazing by cattle has apparently been responsible for decreasing production and retarding plant succession. A change in grazing systems would likely increase the carrying capacity for herbivores.

Grazing a nimals have long been credited with the ability to alter the vigor and species composition of plant communities upon which they feed. This study documents changes in herbage composition and production on mountain meadows following more than a decade of protection from heavy utilization by domestic cattle.

During the spring of 1964, eight exclosures were constructed in mountain meadows near Elk City, Idaho (Fig. 1) as part of a study of meadow ecology by Kowalsky (1964). We relocated these exclosures in 1976 and found five of them to be in a condition which indicated no grazing by large herbivores had occurred since their construction. Kowalsky (1964:34) found that about $85 \%$ of forage utilization in areas adjacent to the exclosures was attributable to cattle, and the remainder to deer, elk and horses. Measurements made inside and immediately adjacent to these exclosures form the basis for this paper.

Authors are wild life research biologist, Idaho Department of Fish and Game, Coeur d'Alene 83814, and research assistant and assistant professor, Forestry and Range, Washington State University, Pullman, 99163.

Authors are grateful to the landowners, Gertrude Maxwell, Wallace B. York, and Harold F. Johnson for allowing the exclosures to be constructed and the studies to be carried out on their property.

Manuscript received December 12, 1979.

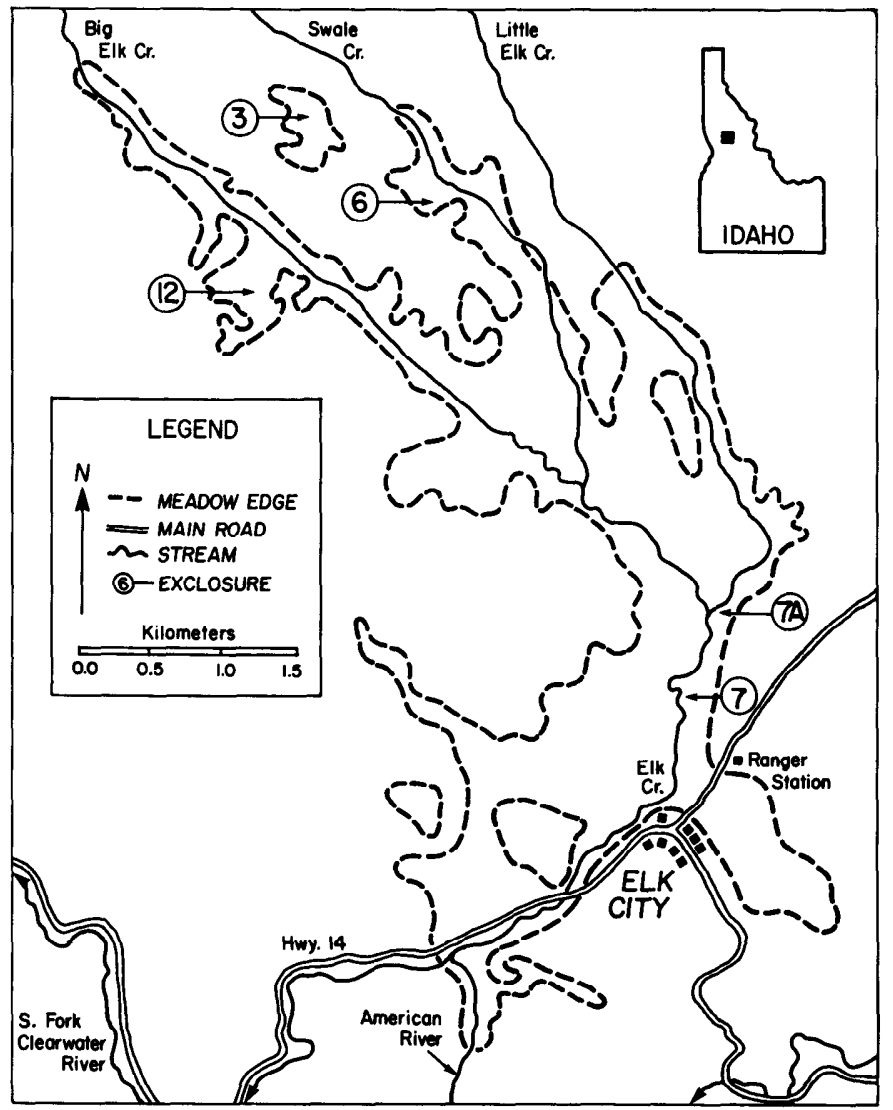

Fig. 1. Map of the study area near Elk City, Idaho. 
Table 1. Weather records for Elk City, Idaho, for the study periods and long-term average. Measurements recorded in degrees celsius and centimeters.

\begin{tabular}{|c|c|c|c|c|c|c|c|c|c|c|}
\hline & \multicolumn{2}{|c|}{ May } & \multicolumn{2}{|c|}{ June } & \multicolumn{2}{|c|}{ July } & \multicolumn{2}{|c|}{ August } & \multicolumn{2}{|c|}{ Annual } \\
\hline & $\begin{array}{l}\text { Avg. } \\
\text { temp. }\end{array}$ & $\begin{array}{l}\text { Total } \\
\text { ppt. }\end{array}$ & $\begin{array}{l}\text { Avg. } \\
\text { temp. }\end{array}$ & $\begin{array}{l}\text { Total } \\
\text { ppt. }\end{array}$ & $\begin{array}{l}\text { Avg. } \\
\text { temp. }\end{array}$ & $\begin{array}{l}\text { Total } \\
\text { ppt. }\end{array}$ & $\begin{array}{l}\text { Avg. } \\
\text { temp. }\end{array}$ & $\begin{array}{l}\text { Total } \\
\text { ppt. }\end{array}$ & $\begin{array}{l}\text { Avg. } \\
\text { temp. }\end{array}$ & $\begin{array}{l}\text { Total } \\
\text { ppt. }\end{array}$ \\
\hline 1964 & 7.2 & 7.1 & 13.0 & 13.0 & 17.2 & 5.6 & 14.7 & 7.9 & 4.3 & 95.0 \\
\hline 1976 & 9.5 & 9.7 & 11.2 & 11.2 & 16.4 & 5.1 & 14.9 & 6.4 & 4.9 & 78.2 \\
\hline 1977 & 7.0 & 7.4 & 14.3 & 4.3 & 14.4 & 4.3 & 15.2 & 6.1 & 4.7 & 90.2 \\
\hline $\begin{array}{l}\text { Long-term Avg. (14 yr.- } \\
\text { avg. 1964-77) }\end{array}$ & 8.1 & 6.6 & 12.7 & 7.4 & 16.2 & 3.3 & 15.3 & 4.6 & 4.8 & 79.3 \\
\hline
\end{tabular}

\section{Study Area}

Of the five exclosures measured, three were characterized as occurring on dry meadows (Nos. 3, 6 and 12), one on a moist meadow (No. 7A), and one on a wet meadow (No. 7). Kowalsky (1964) found charcoal in all ten soil pits dug in dry meadows and this evidence plus the invasion of small lodgepole pine (Pinus contorta) trees indicated that these sites would return to conifers barring heavy grazing, fire, or other factors which help maintain this seral stage. These sites classify as habitat types within the grand fir (Abies grandis) series according to descriptions by Steele et al. (1976). Similar "derived dry meadow" conditions have been described for western red cedar (Thuja plicata) and western hemlock (Tsuga heterophylla) habitat types in northern Idaho (Larson 1977) and other parts of the Pacific Northwest (Kuramoto and Bliss 1970).

The moist and wet meadows are covered by water each spring, a condition which probably eliminated the invasion of woody plants. All exclosures occurred in the 1,220-1,310 m elevational range and were located on flat or gently sloping ground. The trees surrounding the meadows are primarily lodgepole pine with some Douglas fir (Pseudopsuga menziesii), grand fir and subalpine fir (Abies lasiocarpa) reproducing under the lodgepole pine.

The climate on these mountain meadow a reas is characterized by long winters with abundant snow and a short growing season during the summer. Long-term temperature and precipitation averages for the May-August period are compared with Kowalsky's study period (1964) and ours (1976 and 1977) in Table 1. Average annual precipitation at Elk City is $79.3 \mathrm{~cm}$.

\section{Methods}

All five exclosures were square in shape, $2.4 \mathrm{~m}$ high, $7.6 \mathrm{~m}$ on each side, and constructed with wood posts and hogwire (Fig. 2). During the third week of July, 1976, we installed and measured permanent plots within and adjacent to each of the exclosures. Four transect lines were systematically located within each exclosure. Each transect was $4.0 \mathrm{~m}$ long and contained five plots at $1-\mathrm{m}$ intervals. The transects were equidistant from each other and from the edges of the exclosure.

Metal plot stakes were established at the ends of the transects and a metal tape was stretched between them. Plots were located at $1-\mathrm{m}$ intervals along the tape and consisted of a $20 \times 50 \mathrm{~cm}$ metal frame that was extended perpendicular from the metal tape. The frame was open at one end and was painted so that the observer could visually portion the frame into 3 nested plots: $20 \times 50 \mathrm{~cm}, 20$ $\times 25 \mathrm{~cm}$, an $7 \times 7 \mathrm{~cm}$. The lower left hand inside corner of the plot frame was always even with $0,1,2,3$, or 4 meters along the stretched tape. The lower left-hand side of the frame always contained the $7 \times 7 \mathrm{~cm}$ plot.

Immediately outside the exclosure, we subjectively chose an adjacent area that looked similar physically and vegetationally to inside the exclosure and permanently marked the beginning and ending points of a $20 \mathrm{~m}$ transect. Those points were marked with

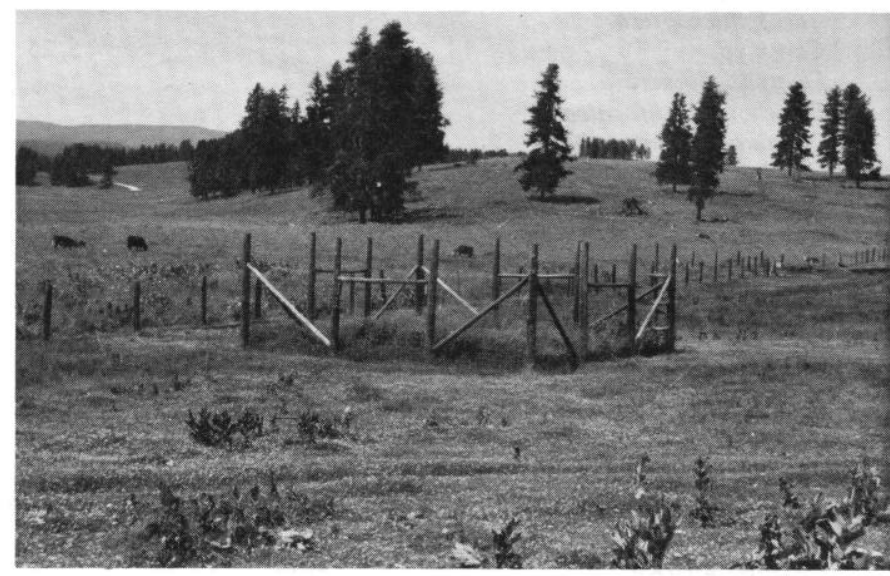

Fig. 2. Main exclosure no. 3 in dry meadow during July, 1976.

large nails about $25 \mathrm{~cm}$ long that were dropped into a $76 \mathrm{~cm}$ long pipe that was pushed in flush with the surface of the ground. A large, galvanized washer, about $5 \mathrm{~cm}$ in diameter was placed under the head of each nail to facilitate relocation. Plots similar to those inside the exclosure were established along a stretched tape between these transect markers and at 1-m intervals.

At each plot, a vertical projection was made to the ground at each inside corner of the plot frame and midway along each side of the frame at the $25 \mathrm{~cm}$ marking. It was then recorded as to whether the projection encountered live herbaceous basal area, bare ground, litter, or moss.

Also, for each plot, we tabulated the presence of all species

Table 2. Ground cover (\%) outside and inside of five exclosures near Elk City, Idaho. ${ }^{1}$

\begin{tabular}{|c|c|c|c|c|c|c|c|c|c|c|c|c|}
\hline & \multicolumn{2}{|c|}{ Excl. 3} & \multicolumn{2}{|c|}{ Excl. 6} & \multicolumn{2}{|c|}{ Excl. 12} & \multicolumn{2}{|c|}{ Excl. 7A } & \multicolumn{2}{|c|}{ Excl. 7} & \multicolumn{2}{|c|}{ Average } \\
\hline & Out & In & Out & In & Out & In & Out & In & Out & In & Out & In \\
\hline Herbaceous & 11.7 & 9.2 & 8.3 & 15.8 & $14.2^{*}$ & 6.7 & 15.8 & 14.2 & 13.3 & 14.2 & 12.6 & 12.0 \\
\hline Bare ground & 7.5 & 6.7 & $9.2^{*}$ & 0.8 & 18.3 & 10.0 & $14.2^{*}$ & 0.8 & $35.8^{*}$ & 20.0 & 17.0 & 7.7 \\
\hline Litter & $21.7 * *$ & 75.8 & 66.7 & 63.4 & $50.0^{* *}$ & 83.3 & $47.5^{* *}$ & 84.2 & $19.2^{* *}$ & 64.1 & $41.1^{*}$ & 74.1 \\
\hline Moss & $59.1 * *$ & 8.3 & 15.8 & 20.0 & $17.5^{* *}$ & 0.0 & $22.5^{* *}$ & 0.8 & $31.7 * *$ & 1.7 & $29.3 *$ & 6.2 \\
\hline Total & 100.0 & 100.0 & 100.0 & 100.0 & 100.0 & 100.0 & 100.0 & 100.0 & 100.0 & 100.0 & 100.0 & 100.0 \\
\hline
\end{tabular}

${ }^{1}$ Data represent percentage of hits out of 120 points

* and ** indicate significant difference between outside and inside measurements at the .05 and .01 confidence levels, respectively. 
rooted in each of the 3 nested plots. However, only data from the smallest and largest nested plots are reported here (Table 3) and they are referred to as microplot and macroplot, respectively. The method is based on procedures proposed by Hyder et al. 1963.

In order to measure the effect of continous heavy untilization on herbage production, we constructed add-on exclosures to each of the five exclosures already standing in fall, 1976. Each new exlosure was $4 \mathrm{~m}$ by $5 \mathrm{~m}$ in size, with long side parallel to the existing exclosure. New exclosures were constructed with metal fence posts and one layer of $1.2 \mathrm{~m}$ high hogwire and a single strand of barbed wire along the top to keep out cattle. On August 8 and 9, 1977, we clipped five systematic-random samples of herbage production from each of the two exclosures on each of the five sites. All vegetation was clipped to ground level within a $20 \times 50 \mathrm{~cm}$ frame for each sample. Each exclosure was stratified to represent the variation in vegetation, and production sample plots were randomly placed in each stratum. Each sample was kept separate in a paper sack and air-dried before weighing. When each plot was clipped, we estimated percent of the production that consisted of grasses, sedges, rushes and forbs. All add-on exclosures were removed when clippings were made.

A series of questions were asked of the landowners on whose

Table 3. Frequency values (\%) for graminoids and forbs occurring outside and inside of five exclosures after twelve grazing seasons following exclosure construction. ${ }^{1}$

\begin{tabular}{|c|c|c|c|c|c|c|c|c|c|c|}
\hline \multirow[b]{2}{*}{ Species } & \multicolumn{2}{|c|}{$\begin{array}{c}\text { Excl. } 3 \\
\text { (dry) }\end{array}$} & \multicolumn{2}{|c|}{$\begin{array}{c}\text { Excl. } 6 \\
\text { (dry) }\end{array}$} & \multicolumn{2}{|c|}{$\begin{array}{l}\text { Excl. } 12 \\
\text { (dry) }\end{array}$} & \multicolumn{2}{|c|}{$\begin{array}{c}\text { Excl. 7A } \\
\text { (moist) }\end{array}$} & \multicolumn{2}{|c|}{$\begin{array}{c}\text { Excl. } 7 \\
\text { (wet) }\end{array}$} \\
\hline & Out & In & Out & In & Out & In & Out & In & Out & In \\
\hline \multicolumn{11}{|l|}{ Graminoids } \\
\hline Agropyron repens & $0 / 10$ & $0 / 15$ & & & $55 / 80$ & $5 / 50$ & & & & \\
\hline Agropyron sp. & & & & & $5 / 20$ & $0 / 0$ & & & & \\
\hline Agrostis alba & & & & & & & $90 / 100$ & $0 / 20$ & $75 / 95$ & $35 / 70$ \\
\hline Bromus marginatus & & & & & $10 / 65$ & $0 / 35$ & & & & \\
\hline Bromus polyanthus & & & & & $0 / 30$ & $0 / 40$ & & & & \\
\hline Carex microptera & & & & & & & $0 / 0$ & $25 / 45$ & & \\
\hline Carex sp. & & & $5 / 25$ & $5 / 25$ & & & $5 / 55$ & $25 / 85$ & $70 / 90$ & $100 / 100$ \\
\hline Dactylis glomerata & & & & & $0 / 5$ & $5 / 40$ & & & & \\
\hline Danthonia californica & & & & & & & $0 / 0$ & $10 / 20$ & & \\
\hline Danthonia intermedia & $20 / 70$ & $0 / 0$ & & & & & & & & \\
\hline Deschampsia caespitosa & & & & & & & $0 / 10$ & $10 / 35$ & $15 / 25$ & $0 / 0$ \\
\hline Festuca sp. & & & $0 / 5$ & $0 / 0$ & & & & & & \\
\hline Juncus balticus & & & & & & & & & $5 / 10$ & $0 / 15$ \\
\hline Juncus sp. & & & $0 / 0$ & $0 / 5$ & $0 / 10$ & $5 / 10$ & $55 / 90$ & $0 / 0$ & & \\
\hline Phleum pratense & $40 / 70$ & $0 / 15$ & $5 / 30$ & $0 / 20$ & $0 / 30$ & $5 / 20$ & $45 / 90$ & $10 / 45$ & $20 / 50$ & $0 / 5$ \\
\hline Poa compressa & $0 / 25$ & $0 / 20$ & & & & & & & & \\
\hline Poa pratensis & $95 / 100$ & $100 / 100$ & $95 / 100$ & $95 / 100$ & $85 / 100$ & $30 / 80$ & $25 / 50$ & $80 / 95$ & $0 / 5$ & $5 / 5$ \\
\hline Scirpus microcarpus & & & & & & & & & $15 / 30$ & $0 / 0$ \\
\hline Stipa columbiana & $0 / 0$ & $0 / 35$ & $10 / 50$ & $30 / 85$ & $0 / 0$ & $5 / 25$ & & & & \\
\hline \multicolumn{11}{|l|}{ Forbs } \\
\hline Achillea millifolium & $85 / 100$ & $45 / 85$ & $55 / 100$ & $55 / 100$ & $65 / 95$ & $65 / 95$ & $5 / 35$ & $25 / 80$ & & \\
\hline Agoseris sp. & $0 / 0$ & $10 / 40$ & & & & & & & & \\
\hline Antennaria rosea & $0 / 10$ & $10 / 15$ & $15 / 75$ & $15 / 75$ & & & & & & \\
\hline Arenaria macrophylla & & & $0 / 15$ & $0 / 0$ & & & & & & \\
\hline Arenaria seriphylifolia & $10 / 20$ & $0 / 5$ & $45 / 80$ & $0 / 30$ & $0 / 20$ & $0 / 0$ & & & & \\
\hline Aster conspicuous & & & & & & & $0 / 0$ & $20 / 85$ & & \\
\hline Campanula rotundifolia & $0 / 5$ & $0 / 0$ & $25 / 70$ & $15 / 30$ & & & & & & \\
\hline Circium sp. & & & & & $0 / 25$ & $0 / 0$ & & & & \\
\hline Collomia linearis & $0 / 15$ & $0 / 0$ & $20 / 60$ & $0 / 0$ & $5 / 60$ & $0 / 0$ & $0 / 0$ & $5 / 25$ & & \\
\hline Collinsia parviflora & $5 / 5$ & $0 / 5$ & & & & & & & & \\
\hline Erigeron sp. & $0 / 0$ & $0 / 5$ & & & & & & & & \\
\hline Fragaria virginiana & $0 / 5$ & $25 / 70$ & $5 / 35$ & $0 / 5$ & $0 / 0$ & $55 / 85$ & & & & \\
\hline Fraseria albicaulis & & & & & & & $0 / 0$ & $0 / 25$ & & \\
\hline Geranium sp. & & & $0 / 5$ & $0 / 0$ & & & & & & \\
\hline Hypericum perforatum & $0 / 0$ & $0 / 20$ & & & & & & & & \\
\hline Lathyrus sp. & & & $0 / 0$ & $35 / 75$ & $0 / 0$ & $0 / 5$ & & & & \\
\hline Linnea borealis & & & & & & & $5 / 5$ & $0 / 5$ & & \\
\hline Microsteris sp. & $0 / 5$ & $0 / 0$ & $10 / 50$ & $0 / 0$ & & & & & & \\
\hline Penstemon sp. & & & $5 / 35$ & $25 / 80$ & $0 / 5$ & $5 / 30$ & & & & \\
\hline Perideridia gairdneri & $0 / 0$ & $10 / 75$ & & & $0 / 20$ & $0 / 0$ & $0 / 0$ & $0 / 30$ & & \\
\hline Plantago lanceolata & & & & & & & $5 / 15$ & $0 / 0$ & & \\
\hline Polygonum douglasii & & & $5 / 20$ & $0 / 0$ & & & & & & \\
\hline Potentilla glandulosa & & & & & $0 / 0$ & $0 / 10$ & & & & \\
\hline Potentilla gracilis & $15 / 85$ & $40 / 95$ & $20 / 80$ & $35 / 100$ & $30 / 70$ & $10 / 40$ & $20 / 80$ & $30 / 70$ & & \\
\hline Prunella vulgaris & & & $0 / 0$ & $5 / 10$ & $0 / 10$ & $0 / 5$ & $10 / 35$ & $0 / 0$ & & \\
\hline Ranunculus uncinatus & $10 / 30$ & $35 / 55$ & $5 / 45$ & $5 / 15$ & $30 / 55$ & $5 / 10$ & $0 / 15$ & $5 / 15$ & & \\
\hline Rumex acetosella & $5 / 30$ & $5 / 5$ & $5 / 30$ & $0 / 10$ & $0 / 25$ & $20 / 95$ & & & & \\
\hline Sedum douglasii & $20 / 55$ & $25 / 65$ & $50 / 100$ & $40 / 95$ & & & & & & \\
\hline Senecio sp. & $0 / 0$ & $0 / 5$ & & & & & & & & \\
\hline Sidalcea oregana & & & & & & & $0 / 0$ & $10 / 25$ & & \\
\hline Taraxacum sp. & $30 / 70$ & $30 / 65$ & $45 / 95$ & $40 / 95$ & $30 / 90$ & $0 / 50$ & $15 / 80$ & $10 / 35$ & $0 / 5$ & $0 / 0$ \\
\hline Trifolium sp. & $0 / 20$ & $0 / 0$ & $10 / 20$ & $5 / 10$ & $55 / 80$ & $5 / 30$ & $100 / 100$ & $5 / 25$ & $10 / 25$ & $0 / 0$ \\
\hline Veratrum californicum & & & & & & & $0 / 15$ & $0 / 10$ & & \\
\hline
\end{tabular}

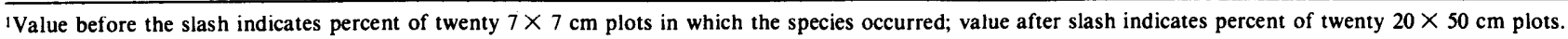


property exclosures occurred to obtain information on history of grazing as well as amount and season of use, and other information that might help us interpret our findings.

The words "significant" and "highly significant," when used in reference to specific findings, indicate statistical probability at the .05 and .01 levels, respectively.

\section{Dry Meadows - Heavy Use}

\section{Results}

These exclosures, numbers 3 and 6 , were constructed on areas classified as dry meadows. Both had received heavy utilization from cattlc continuously during the May 1 and through October 1 period for many years, and long before this study began in 1964 . No seeding, fertilizing, or change in use patterns occurred between 1964 and 1976. Both meadows had the appearance of heavy utilization; however, exclosure no. 6 was closer to water and for that reason probably received heavier livestock use over the years. Exclosure 3 was adjacent to conifers that provided some shade, especially during winter. This may have caused snow to accumulate more than on exclosure 6 , making it more moist.

Differences in moss and litter were highly significant between inside and outside of exclosure 3 (Table 2). Whereas, exclosure 6 showed significantly less bare ground inside than outside.

Columbia needlegrass (Stipa columbiana) and cinquefoil (Potentilla gracilis) were the two herbaceous species most dramatically reduced in abundance (Table 3 ). Additional species that were reduced with grazing by $40 \%$ frequency or more at one or the other of the exclosure sites included: mountain dandelion (Agoseris sp), peavine (Lathyrus sp) beard-tongue (Penstemon sp), false-caraway (Perideridia gairdneri). Seven species were increased under grazing at both exclosure sites: timothy (Phleum pratense), annual sandwort (Arenaria seriphylifolia), harebell (Campanula rotundifolia), annual collomia (Collumia linearis), annual microsteris (Microsteris sp.) sheep sorrel (Rumex acetosella), and clover (Trifolium $\mathrm{sp}$ ). Timber oatgrass (Danthonia intermedia) increased with grazing on the one area where it occurred. Other species showed little differences in frequency inside vs. outside exclosures, or conflicting differences between the exclosure sites.

Herbage production for grasses and forbs did not vary significantly between the main exclosure and the add-on, except for the forbs on the exclosure 6 site (Table 4). In this case there was a highly significant difference between forb production inside vs. outside, indicating that continous heavy grazing had reduced the vigor of forbs. Because of this, total herbage production was only about one-half as much in the grazed area as it was inside the exclosure, a highly significant difference.

\section{Dry Meadow - Light Use}

Exclosure 12 is on a dry meadow that was seeded to brome grass shortly before exclosure construction in 1964. In about 1974, some nitrate fertilizer was applied to the areas adjacent to the exclosure but not in it. For many years, since at least 1964, cattle grazing has been relatively light and in a consistent pattern - a week or ten days in early July and again during the month of October.

Despite the lighter utilization on this area, ground cover measurements showed similar findings to exclosure 3 (Table 2).
Several species were more abundant outside the exclosure, indicating that they were favored by grazing: quackgrass (Agropyron repens), brome-grass (Bromus marginatus), Kentucky bluegrass (Poa pratensis), annual collomia, cinquefoil, buttercup (Ranuculus uncinatus), dandelion (Taraxacum $\mathrm{sp}$ ), and clover.

Species which appeared to decrease with grazing were: orchard grass (Dactylis glomerata), Columbia needlegrass, strawberry (Fragaria virginiana), beard-tongue, and sheep sorrel.

Herbage production was somewhat higher outside the exclosure, but not significantly so (Table 4). This increase may be explained by the application of nitrate fertilizer outside the exclosure. Forb production was significantly higher outside the exclosure but grass production was only slightly higher.

\section{Moist Meadow - Heavy Use}

Exclosure 7A was located adjacent to Little Elk Creek on a site classified as moist. No seed or fertilizer was applied during the 1964-76 period. Heavy grazing by cattle occurred each year from about May 1 until they were forced off by snow in November.

The ground cover on this area showed the same relationships of ungrazed to grazed as occurred on the other areas (Table 2). Bare ground and moss were both significantly greater outside the exclosure than inside.

Species which showed marked increases with grazing were: redtop (Agrotis alba), rush (Juncus sp), timothy, selfheal (Prunella vulgaris), dandelion, and clover. Species which showed obvious decreases with grazing included: mountain sedge (Carex microptera), sedge (Carex sp), Kentucky bluegrass, yarrow (Achillea millifolium), aster (Aster conspicuous), annual collomia, elkweed (Fraseria albicaulis), false caraway, and sidalcea (Sidalcea oregana).

Herbage production was significantly higher inside the exclosure than outside (Table 4). Sedge and forb production were higher in the exclosure and grass production was higher outside. Increases in redtop and timothy outside the exclosure were responsible for the increased grass production with grazing. However, this was apparently at the expense of the sedge and forb production which declined dramatically.

\section{Wet Meadow - Heavy Use}

Exclosure 7 was located next to Elk Creek and was wet during spring and early summer. Cattle probably do not make much use of the area until late June because of the wet condition. However, they have access to it from May 1 until November, the same grazing plan as for area 7A. No seeding or fertilizing has occurred on this area for many years.

Bare ground and moss were significantly greater outside the exclosure than inside. Litter was more abundant inside and herbaceous ground cover was about the same inside and out (Table 2).

Species which occurred more frequently outside the exclosure and therefore favored by grazing included: redtop, tufted hairgrass (Deschampsia caespitosa), bulrush (Scirpus microcarpus), timothy, and clover (Table 3). Sedges were more common where protected from grazing. Herbage production inside vs. outside the exclosure was not significantly different (Table 4).

Table 4. Average herbage production $(\mathrm{g} / 20 \times 50 \mathrm{~cm}$ plot) outside vs. inside five exclosures.1

\begin{tabular}{|c|c|c|c|c|c|c|c|c|c|c|}
\hline & \multicolumn{2}{|c|}{ Excl. 3} & \multicolumn{2}{|c|}{ Excl. 6} & \multicolumn{2}{|c|}{ Excl. 12} & \multicolumn{2}{|c|}{ Excl. 7A } & \multicolumn{2}{|c|}{ Excl. 7} \\
\hline & Out & In & $\overline{\text { Out }}$ & In & Out & In & Out & In & Out & In \\
\hline $\begin{array}{l}\text { Sedges } \\
\text { Grasses } \\
\text { Forbs } \\
\text { Other }\end{array}$ & $\begin{array}{l}9.4 \\
7.9\end{array}$ & $\begin{array}{l}8.8 \\
8.3\end{array}$ & $\begin{array}{l}6.2 \\
5.6^{* *}\end{array}$ & 16.1 & $\begin{array}{l}13.5 \\
15.3^{* *}\end{array}$ & $\begin{array}{r}11.6 \\
9.5\end{array}$ & $\begin{array}{c}2.7^{* *} \\
34.6^{*} \\
1.3^{*} \\
2.8 \\
\end{array}$ & $\begin{array}{r}24.6 \\
17.4 \\
11.0 \\
2.8 \\
\end{array}$ & $\begin{array}{r}35.8 \\
8.5 \\
0.0 \\
\end{array}$ & $\begin{array}{r}37.8 \\
2.5 \\
1.0 \\
\end{array}$ \\
\hline Total & $\overline{17.3}$ & $\overline{17.1}$ & $11.8 * *$ & 22.3 & 28.8 & 21.1 & $41.4^{*}$ & 55.8 & 44.3 & 41.3 \\
\hline
\end{tabular}

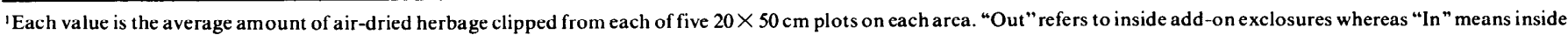
old exclosures.

${ }^{*}$ and $* *$ indicate significant difference between outside and inside measurements at the .05 and .01 confidence levels, respectively. 


\section{Discussion}

Our measurements indicated some changes in plant composition occurred between inside vs. outside the exclosures after they were constructed in 1964. Since pre-exclosure vegetation measurements are not available, it is impossible to determine whether the greatest changes occurred with continued heavy grazing outside the exclosures, or with complete protection, except for small herbivores, inside the exclosures. However, since there is a long history of heavy utilizaton of these meadows by large herbivores, we suspect that greater changes came about as a result of protection from grazing than continuance of the status quo.

\section{Changes in Ground Cover}

Results were consistent on almost all sites in that percentages of bare ground and moss were much higher outside than inside the exclosures. Conversely, litter was usually higher inside the exclosures. Herbaceous basal area did not show a consistent pattern and averaged about the same percent outside as inside. It is difficult to say that grazing caused more bare ground and moss since the increased litter on the ungrazed areas may have covered the bare ground and moss and therefore decreased the likelihood of their being measured. All that can be concluded is that protection from grazing increases litter; not an unexpected finding.

\section{Changes in Species Composition and Density}

For those species that occurred on two or more of the five areas, the following were consistently more common outside the exclosurc than inside and therefore can be considered as favored by heavy grazing: redtop (moist and wet sites), timothy (all sites), annual sand wort (dry sites), harebell (dry sites), annual microsteris (dry sites), dandelion (all sites), and clover (all sites). Similar results were noted by Bonham (1972) for several closely related species on grazed alpine hairgrass meadows in Colorado and Wyoming. Annual collomia increased with grazing on the three dry sites but decreased with grazing on the moist site. Species which consistently showed a decline with grazing were: sedges (wet and moist sites), and Columbia needlegrass, peavine, and beard-tongue (dry sites). Our findings with regard to sedges are in contrast to those of Sanderson (1967) where sedges on heavily grazed wet and dry meadows of the High Sierra of Central California were more plentiful than grasses. However, on a Douglas fir-ponderosa pine (Pinus ponderosa) - Kentucky bluegrass community in northeastern Oregon, Krueger and Winward (1974) found that elk sedge (Carex geyeri) was significantly lower in frequency on an area grazed by cattle as compared to where no cattle grazed.

The species which occurred on only one of the five study areas but showed decreases on the grazed area of $25 \%$ or more in frequency in the macroplots are as follows: mountain sedge, orchard grass, mountain dandelion, aster, elkweed, and sidalcea. Those species showing increases of $25 \%$ or more with grazing were bromegrass, timber oatgrass, bulrush, and thistle (Circium sp).

\section{Changes in Herbage Production}

The month of June was exceptionally dry during 1977 (Table 1) and this undoubtedly affected the amount of production occurring on all of the sites. However, we suspect that the relative production inside vs. outside the exclosures would remain constant even under more normal moisture conditions. Patton and Judd (1970) found considerable variation between years in herbage production on meadow sites in Arizona and New Mexico but that there was a consistency in pattern of production among sites.

Two exclosures, 6 and 7A, showed significant reductions of 47 and $26 \%$, respectively, in herbage production in the grazed areas, compared with the ungrazed. Both of these areas endured heavy cattle use over the years. Exclosure 3 also was subjected to heavy grazing but production inside and outside the exclosure was essentially the same. Our photos indicated less production on the grazed area, but the sampling technique did not verify the difference. Exclosure 12 showed slightly more production on the grazed area, but that can be explained by the nitrate fertilization that occurred there. Production was not significantly different between the grazed and ungrazed areas at the wet site of exclosure 7.

Kowalsky manually clipped plants to simulate grazing within the exclosures in 1964. He used eight 9.6 square foot plots in each exclosure and applied four treatments: clipping on June 9 , on both June 9 and June 30 , on June 30 , and no clipping for the control. He clipped all plots on July 28 and compared overall production for each treatment. The only treatment which produced significantly less production than the control was the one which most closely simulated season-long grazing-June 9 and June 30. The moist meadows (including no. 7A) produced 32\% less herbage under this treatment than the control. The dry meadows (including nos. 3, 6 and 12 ) produced $35 \%$ less herbage. Our findings generally confirm those of Kowalsky. The exclosure at site 7 was not sampled by Kowalsky and consequently we have nothing to compare with our results, which indicate no effects of grazing on total production. As mentioned earlier, this may be due to the occurrence of standing water on the site until later in the growing season, allowing the plants to produce and store some reserves before grazing commences.

\section{Conclusions}

Heavy season-long grazing by cattle changed species composition and lowered herbage production on dry and moist mountain meadows. In a wet meadow, species composition was altered, but total production was not affected by grazing, possibly because of the effects of standing water on delaying grazing. Results from the study by Kowalsky (1964) suggest that grazing would have a less detrimental impact on meadow vegetation if it was done early or late in the growing season, rather than continuously. Plants need a rest period in which to produce foliage so they can store food reserves for initiating growth the following year. An appropriate grazing system would probably increase the production of forage and consequently increase the carrying capacity for herbivores in future years.

\section{Literature Cited}

Bonham, C.D. 1972. Vegetation analysis of grazed and ungrazed alpine hairgrass meadows. J. Range Manage. 25:276-279.

Hyder, D.N., C.E. Conrad, P.T. Tueller, L.D. Calvin, C.E. Poulton, and F.A. Sneva. 1963. Frequency sampling in sagebrush vegetation. Ecology 44:740-746.

Kowalsky, S.I. 1964. Ecology of mountain meadows and use by elk. Unpub. M.S. Thesis. University of Idaho, Moscow. $51 \mathrm{p}$.

Krueger, W.C., and A.H. Winward. 1974. Influence of cattle and big game grazing on understory structure of a Douglas fir, Ponderosa pine, Kentucky blue grass community. J. Range Manage. 27:450-453.

Kuramoto, R.T., and L.C. Bliss. 1970. Ecology of subalpine meadows in the Olympic mountains, Washington. Ecol. Monogr. 40:317-347.

Larson, M.J. 1977. Regeneration of meadow-associated forest stands of central north Idaho. Unpub. Ph.D. thesis (forestry), Univ. of Idaho, Moscow. $106 \mathrm{p}$.

Patton, D.R., and B.I. Judd. 1970. The role of wet meadows as wildlife habitat in the southwest. J. Range Manage. 23:272-275.

Sanderson, H.R. 1967. Herbage production on high Sierra Nevada meadows. J. Range Manage. 20:255-256.

Steele, R., S.F. Arno, and R.D. Pfister. 1976. Preliminary forest habitat types of the Nezperce National Forest. U.S. Forest Serv., Reg. 1 and Int. Forest and Range Exp. Sta. Bull., Missoula. 71 p. 